\title{
A Review and Comparative Analysis on Energy Transition in China's Three Emerging Urban Agglomerations
}

\author{
Jianchao Hou ${ }^{1}$, Jinhua Jian ${ }^{1, \text { a }}$ and Pingkuo Liu ${ }^{1}$ \\ ${ }^{1}$ College of Economics and Management, Shanghai University of Electric Power, Shanghai 200090, China
}

\begin{abstract}
With the aggravation of environmental pollution and the overuse of fossil energy, a sustainable transition to using the low-carbon and clean energy is perceived to be an inevitable trend. The Beijing-TianjinHebei, the Yangtze River Delta and the Pearl River Delta are the three most important economic circles in China. One purpose of energy transition in those Three Urban Agglomerations is to enable the energy system to have a higher share of clean energy. This paper introduces the current situation in terms of energy endowment, production and consumption in the three urban agglomerations, discusses the policy environment from the aspects of development planning, supporting mechanism and policy tools. We further analyse the barriers of the energy transition in the three urban agglomerations by using Institution-Economy-TechnologyBehaviour (IETB) conceptual model. Through this research, we know that reducing the carbon emissions is a priority in energy transition and increasing the utilization of renewable energy has become the consensus in the three urban agglomerations. In addition, reasonable energy development policies can impel the energy investment and the technology innovation to accelerate energy transition. Moreover, in the designated "highly polluting" industry sectors, energy supply enterprises and energy-consuming enterprises establish greendevelopment incentive mechanisms and adopt technological innovation in order to promote energy transition.
\end{abstract}

\section{Introduction}

Driven by the international agreements on limiting the effects of climate change, transition to low carbon and clean energy is perceived to be offering many new opportunities. Academic debates over the spatial implications of energy transition and the realization of sustainable futures have predominantly focused on urban areas, which has resulted in the notion of "Urban Energy Transition"[1]. In 2012, the idea of "Energy Revolution", was officially introduced by previous President $\mathrm{Hu}$ Jintao during the 18th national congress of the Communist party

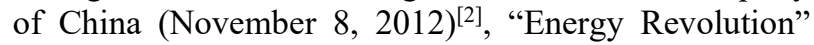
holds the revolution idea of energy production and consumption $^{[3]}$. And then, in June 2014, Chinese President $\mathrm{Xi}$ Jinping also called for an "Energy Revolution", specifying on reducing energy consumption, increasing energy supply, improving energy technology and institutional reform. The Sixth Meeting of the Central Financial Leading Group (proposed by Chairman Xi Jinping), and in the first half year of 2017, the initial strategy about the national energy production and consumption was officially published in full text (published by National Development and Reform Commission). The three urban agglomerations are the centers of production and consumption in china, and hence also the centers of energy consumption. It is challenging for China to promote energy transition at this stage $^{[4]}$. As the three most developed urban agglomerations in China, the Beijing-Tianjin-Hebei
(BTH), the Yangtze River Delta (YRD) and the Pearl River Delta (PRD) have recognized the importance of energy transition earlier and begun to advance their own process intensively. They also have the capability to support their own energy transition ${ }^{[5]}$.

In this paper, we explore the Institution-EconomyTechnology-Behaviour (IETB) conceptual model impacts of the energy transition process in the three urban agglomerations at the beginning of " 12 th-Five-Year-Plan period (2011-2015)". The BTH region owns the wind power installed capacity and photovoltaic power generation capacity (ranking third and seventh in china respectively), although its resource advantage is relying heavily on coal at present. The YRD being a leading economic development region ${ }^{[6]}$, its integrated development of distributed energy technology, energy storage technology and information technology promotes the efficiency of energy systems. The PRD region is now known as the most potential urban agglomeration in adjusting and upgrading the industrial structure, however, it is not very active in advancing energy technology. In the new round of energy structure adjustment ${ }^{[7]}$, with a clear superiority of clean energy accounting for nearly half of the total energy consumption, the PRD region may have, arguably, entered its own "Green Leader" era in China. The objective of this study is to understand the relationship among energy institution, energy economics, energy technology, behaviour of participants and energy transition,

\footnotetext{
a Corresponding author: jianjinhua@mail.shiep.edu.cn
} 
This paper uses the Institution-Economy-TechnologyBehaviour (IETB) conceptual model to analyse the energy transition. This conceptual model is the same as neither PEST analysis nor SWOT analysis. The PEST analysis is an analysis tool from the four factors of Political, Economic, Social and Technological ${ }^{[8]}$, the SWOT analysis model analysing four factors of Strengths, Weaknesses, Opportunities and Threats. The PEST and the SWOT above-mentioned fail to analyse some issue from the perspective of institutional, however, institutional transition is the foundation of energy transition $^{[8,9]}$. Institution transition is considered as an effective pathway for energy transition ${ }^{[8]}$. Therefore, the Institution-Economy-Technology-Behaviour (IETB) conceptual model is proposed. In this way, energy laws and regulations, economic structure of energy, innovative technologies of energy, and behaviour of governments and enterprises are used for comprehensively analysing the energy transition of three urban agglomerations. However, there are still quite a few problems about the energy transition in China. And the primary obstacle is that the all departments have a simplified and stylized understanding of the energy transition ${ }^{[10]}$. Under the background of this situation, the energy transition in three urban agglomerations have the following problems.

[Problem 1] What are the impacts of the energy transition in the three urban agglomerations on all aspects of China's energy transition?

[Problem 2] What are the difficulties of the energy transition in the three urban agglomerations?

[Problem 3] How can the three urban agglomerations achieve better energy transition in the future?

\section{Current situation}

It is well known that energy situation is the basis of energy transition. The key driving forces are composed of energy endowment, energy production, energy structure and demand composition changes.

\subsection{Energy development}

\subsubsection{Status in Beijing-Tianjin-Hebei (BTH)}

Energy endowment: The energy resources distribution in the BTH region is described uneven. Even though Hebei province is characterized by abundant energy resources such as coal, oil, wind, solar and geothermal energy ${ }^{[1]}$. Whereas, there is only a small-scale coal energy and hydropower in Beijing ${ }^{[12]}$. Meanwhile, Tianjin contains a small amount crude oil and nature gas ${ }^{[13]}$.

Energy production: According to the Statistical Yearbook (2019), it has been found that the raw coal and the crude oil take up approximately 70 percent of the BTH region's gross primary energy production and they are also a major part of energy consumption. On the one hand, compared with the data in 2011, the total amount of primary energy in 2018 was decreased by 2.9 percent. The number decrease from 17.02 million tce to 16.52 million tce. In addition, the lowest value was 15.16 million tce appeared in 2013. On the other hand, the energy production structure is mainly composed of four resources: the raw coal, the crude oil, the natural gas and the primary electricity. From 2011 to 2018, the average share of the crude oil is the largest in the total energy production, followed by the coal. And the smallest average is the natural gas. The share of four energy sources was presented in Fig 1. Among these four energy resources, it is obvious that the natural gas and the primary electricity are showing a slight increasing trend, to the opposite, the share of the raw coal is getting lower (see Fig 2). Renewable energy is important as an alternative energy source because fossil fuel resources are limited and associated with a number of negative environmental effects, such as global climate change and air pollution.

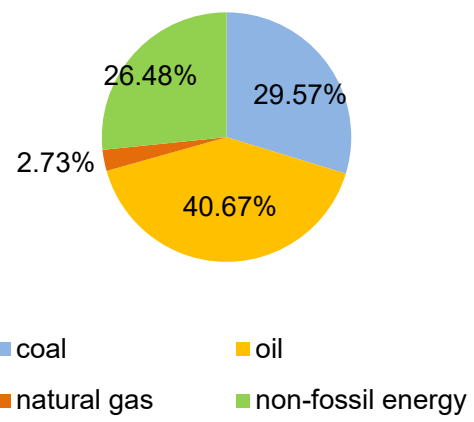

Fig 1. Share of primary energy in BTH

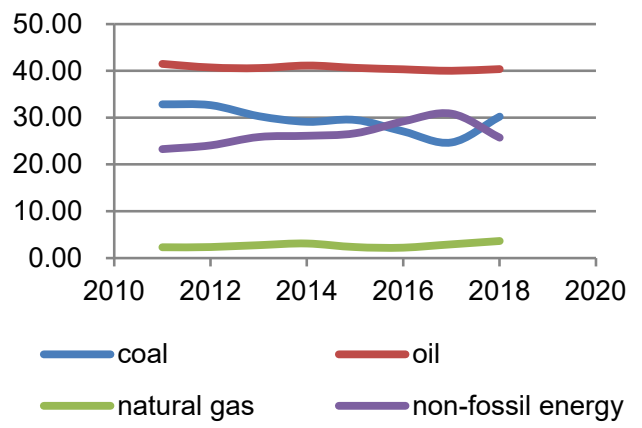

Fig 2. Change trend of primary energy in BTH

Energy consumption: The total energy consumption in the BTH region has an increase tendency. In addition, the total energy consumption in the region far exceeds the total energy production (see Fig 3). For one thing, derived from "Energy Statistics Yearbook (2019)" of the region in 2011-2018, it can be seen that the total energy consumption is increasing year by year. When 2018 came to an end, the total amount of energy consumption was 45812.8 tce which was bigger in comparison to the 41253.7 tce used the year 2011. However, the year-onyear growth rate is declining. Fig 4 presents the change process of the year-on-year growth rate. 


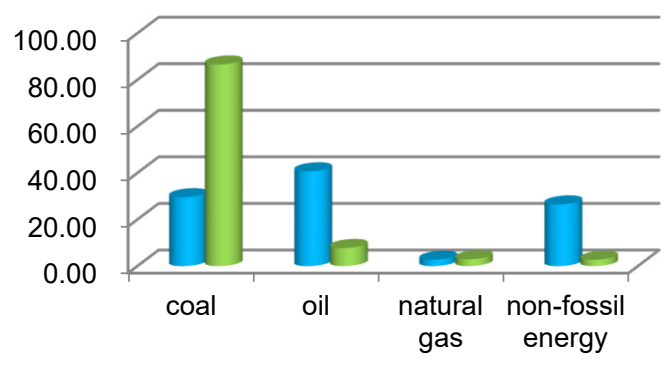

- total energy production $\square$ total energy consumption

Fig 3. Proportion of total production and consumption in BTH

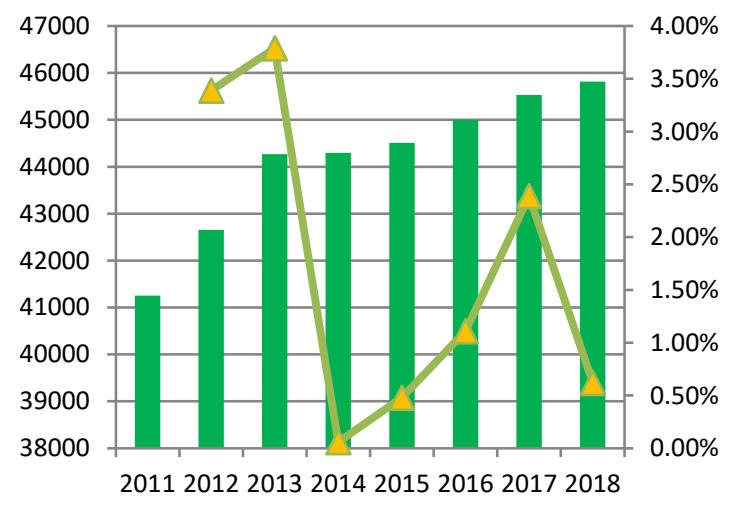

total consumption $\longrightarrow$ YoY growth rate

Fig 4. Change trend of total consumption and growth rate in $\mathrm{BTH}$

Energy transition (ET) in the BTH region has following features. Firstly, core fields of energy transition are focused on transportation, industry and architecture, accounting for $21 \%, 61 \%, 14 \%$ respectively. Secondly, a considerable transition pathway is reducing carbon emissions and increasing the share of clean energy in energy production and consumption. Thirdly, Wang (2009) ${ }^{[14]}$ have been made so far the clean utilization rate of coal has increased, and the share of renewable energy use has increased.

\subsubsection{Status in Yangtze River Delta (YRD)}

Energy endowment: The YRD is the largest energyconsuming urban agglomeration in china ${ }^{[15]}$. However, the primary energy resources in the YRD region are scarce, and the industrial development absolutely depends on heavy energy supply from other provinces. As for renewable energy, it is generous in wind, solar and ocean energy.

Energy production: From the region's energy data (2019), the total production of primary energy remained steadily developing before 2016, but significantly increasing to 5538.71 million tons of standard coal by 2018. In addition, the coal was dominant in energy structure, accounting for the largest share during 20112018 period. The oil and the non-fossil energy shares were similar, the natural gas has the smallest share, as shown in Fig 5. The natural gas and the primary electricity are increasing in energy production structure, which indicates an ongoing transition to cleaner sources (Fig 6).

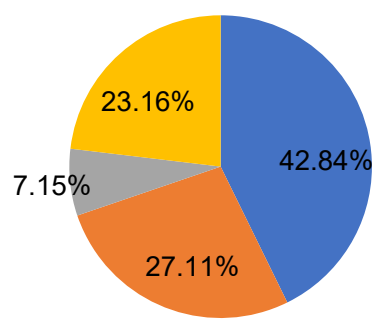

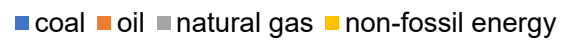

Fig 5. Share of primary energy in YRD

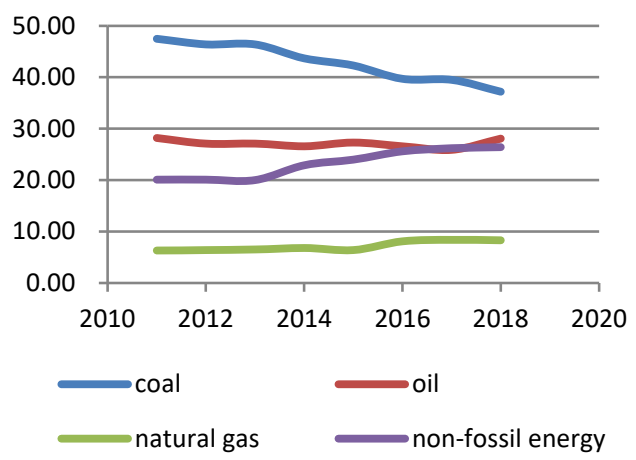

Fig 6. Change trend of primary energy in YRD

Energy consumption: Though the total energy consumption in the YRD region has been continuously rising, the growth rate is gradually slowing down. It is worth mentioning that total energy consumption is more than ten times higher than total energy production. As shown from Fig 7, the most striking thing is that the use of natural gas has the highest share. In addition, while the share of renewable energy has increased, the share of coal has dropped a lot. Regarding the year-on-year growth rate, although it reached a maximum of $4 \%$ in 2013 , it fell to $1.5 \%$ in 2018(see Fig 8).

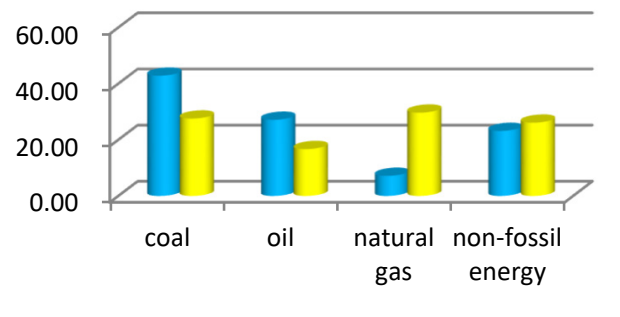

- total energy production total energy consumption

Fig 7. Proportion of total production and consumption in YRD 


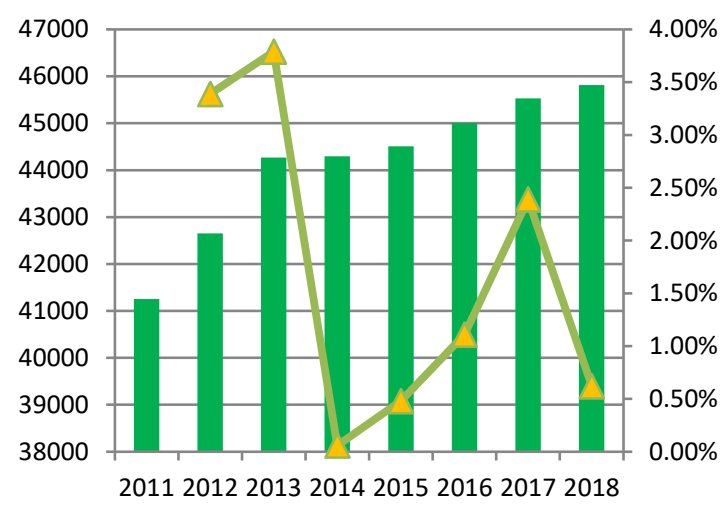

total consumption $\longrightarrow$ YoY growth rate

Fig 8. Change trend of total consumption and growth rate in YRD

The energy transition attributes in the YRD region are divided into three parts. Firstly, renewable energy generation and conventional energy generation are mainly used in the power industry, transportation and energy internet. Secondly, energy transition approach including technological innovation and strengthen the reelectrification of final energy. Thirdly, the transition and development of the YRD region generally showed good trends, but the transition in various fields is still not coordinated $^{[16]}$.

\subsubsection{Status in Pearl River Delta (PRD)}

Energy endowment: The PRD region is located near the coast of southern China. Additionally, the regions' energy resources contain almost no primary energy but it is abundant in wind, solar, biomass and ocean energy ${ }^{[17]}$.

Energy production: The PRD region illustrates an upward trend in primary energy production. By the end of 2018 , total energy production of the region has reached up to 7079.1 million tce, which was more than 45.85 percent in 2011 level. Furthermore, from the average production of each energy from 2011 to 2018 , it can be seen that the share of non-fossil energy is the highest, especially for the share of coal is zero (Fig 9). Energy production structure is estimated by the largest share of primary electricity. And the natural gas increasing tendency for its share (Fig $10)$.

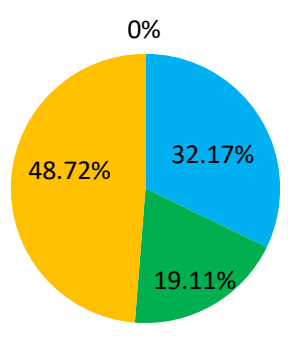

coal $\square$ oil $\square$ natural gas $\square$ non-fossil energy

Fig 9. Share of primary energy in $\mathrm{PRD}$

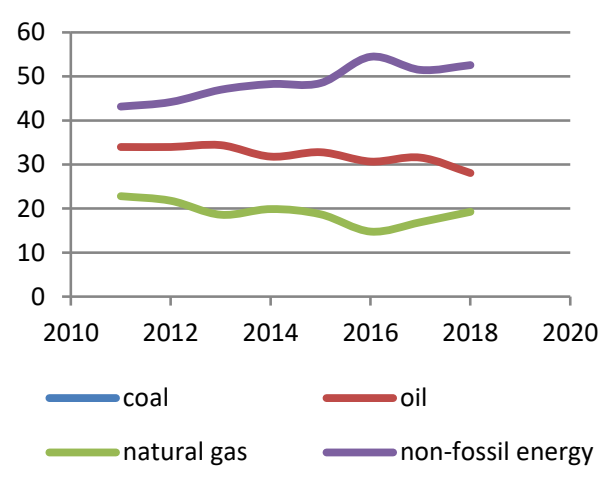

Fig 10. Change trend of primary energy in PRD

Energy consumption: since the 12th Five-Year Plan (2011-2015), the primary energy consumption has been increasing, the total of energy consumption increase from 23318.4 million tce to 30154.7 million tce in 2018. In addition, although the total energy consumption in 2011 was approximately five times the total energy production, the total energy consumption was fallen to four times the total energy production in 2018. The energy production and the consumption structure are extremely asymmetric, the most typical is that although the share of renewable energy is the largest in the production structure, the most used in the consumption structure is still the coal (Fig 11). Finally, the year-on-year growth rate of total energy consumption in the region has declined slightly from 2016 to 2018 , but it's percent is still relatively high compared to the previous five years (2011-2015) (Fig 12).

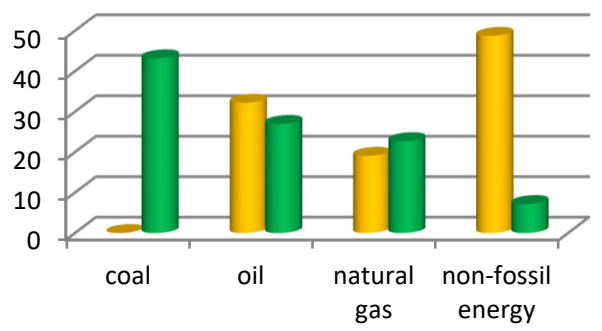

total energy production $\square$ total energy consumption

Fig 11. Proportion of total production and consumption in PRD

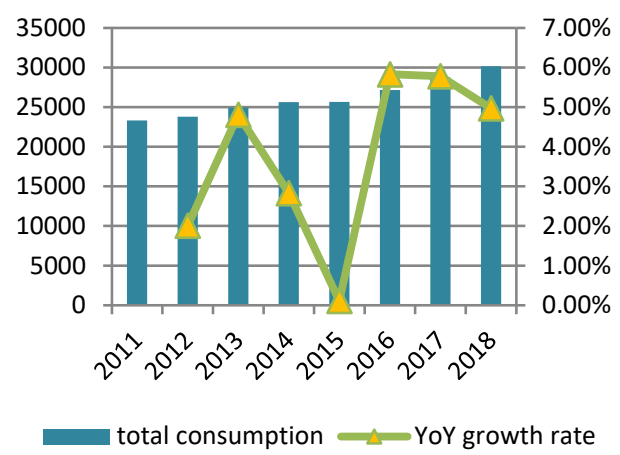

Fig 12. Change trend of total consumption and growth rate in PRD 
The characteristics of energy transition in the PRD region are decomposed into three aspects. Firstly, the key areas are involved some clean energy equipment manufacturing, transportation and electricity industry. Secondly, it is necessary to build a clean and renewable energy industry to form a clean, safe and reliable energy security system, at the same time, it is a priority to speed up the use of renewable energy and improve energy efficiency. Thirdly, at present, the PRD has made remarkable achievement in the industry upgrading, and formed a new development pattern of supply security.

\subsection{Policy environment}

Appropriate policies play important roles in guiding and impelling energy transition ${ }^{[18]}$. Therefore, those Chinese local governments in the three urban agglomerations have their own energy strategy. These energy policies are generally issued by National Development and Reform Commission, national energy administration, and Ministry of Environmental Protection. Each agglomeration governments have issued policies which involves all aspects of the energy transition, such as the development of renewable energy, and the improvement of the energy efficiency. The BTH and the YRD have issued policies which focus on development plan and notice type. Whereas, the PRD release corresponding policies major on development plan and regulation (table $1)$.

Table 1. Energy policy environment of each agglomeration

\begin{tabular}{|c|c|c|}
\hline & Time & Policies \\
\hline \multirow{6}{*}{$\begin{array}{l}\mathrm{B} \\
\mathrm{T} \\
\mathrm{H}\end{array}$} & Aug.2013 & $\begin{array}{l}\text { Beijing Work Plan to Accelerate } \\
\text { Pressure Reduction of Coal Burning } \\
\text { and Clean Energy (2013-2017) }\end{array}$ \\
\hline & Jun.2014 & $\begin{array}{l}\text { Notice of Tianjin New Energy Vehicle } \\
\text { Financial Subsidy Management } \\
\text { Measures }\end{array}$ \\
\hline & Doc.2015 & $\begin{array}{l}\text { Notice on "Relevant Electricity Price } \\
\text { Subsidy Policies for Photovoltaic } \\
\text { Power Generation Projects" }\end{array}$ \\
\hline & Jun.2017 & $\begin{array}{l}\text { Beijing's "13th Five-Year Plan" period } \\
\text { energy development plan }\end{array}$ \\
\hline & Doc.2018 & $\begin{array}{l}\text { "Tianjin Decentralized Wind Power } \\
\text { Development Plan (2018-2025)" }\end{array}$ \\
\hline & Aug.2019 & $\begin{array}{lrr}\text { "Plan for } & \text { Hydrogen } & \text { Energy } \\
\text { Zhangjiakou } & \text { Construction } & (2019- \\
\text { 2035)" } & & \\
\end{array}$ \\
\hline \multirow{3}{*}{$\begin{array}{l}\mathrm{Y} \\
\mathrm{R} \\
\mathrm{D}\end{array}$} & May.2009 & $\begin{array}{l}\text { "Zhejiang Province Photovoltaic and } \\
\text { other new energy promotion and } \\
\text { application and industrial } \\
\text { development plan (2009-2012)" }\end{array}$ \\
\hline & Jun.2014 & $\begin{array}{l}\text { Notice on the Measures for Supporting } \\
\text { Special Funds for Renewable Energy } \\
\text { and New Energy Development }\end{array}$ \\
\hline & Apr.2015 & $\begin{array}{l}\text { Notice of "2015 Annual Construction } \\
\text { Scale of Photovoltaic Power } \\
\text { Generation" }\end{array}$ \\
\hline
\end{tabular}

\begin{tabular}{|c|c|c|}
\hline & Nov.2016 & $\begin{array}{l}\text { Notice on the Measures for Supporting } \\
\text { Special Funds for Renewable Energy } \\
\text { and New Energy Development }\end{array}$ \\
\hline & May.2019 & $\begin{array}{l}\text { "Zhejiang Province Action Plan for } \\
\text { Building a National Clean Energy } \\
\text { Demonstration Province (2018-2020)" }\end{array}$ \\
\hline \multirow{4}{*}{$\begin{array}{l}P \\
R \\
D\end{array}$} & Mar.2010 & $\begin{array}{l}\text { Regulations of Guangdong Province } \\
\text { on Energy Conservation }\end{array}$ \\
\hline & 2014 & $\begin{array}{l}\text { "Development Plan for Solar } \\
\text { Photovoltaic Power Generation in } \\
\text { Guangdong Province (2014-2020)" }\end{array}$ \\
\hline & Jan.2016 & $\begin{array}{l}\text { "Guangdong Onshore Wind Power } \\
\text { Development Plan (2016-2030)" }\end{array}$ \\
\hline & Sep.2019 & $\begin{array}{l}\text { "Notice on Accelerating the } \\
\text { Construction of Renewable Energy } \\
\text { Project Supporting Networking } \\
\text { Projects" }\end{array}$ \\
\hline
\end{tabular}

\section{Analysis and discussion}

Currently, energy transition is still in the initial stage and energy system is still incomplete. To evaluate the development of energy transition in China's three emerging urban agglomerations, this section adopts Institution-Economy-Technology-Behaviour (IETB) conceptual model to analyse the key factors of energy transition ${ }^{[19]}$.

\subsection{Institution aspect}

In terms of achieving low-carbon transition, the three urban agglomerations has made some efforts on institutional. However, due to the difference in economic status, demographic conditions and resource endowments, the focus of energy related institutional are different among urban agglomerations (Table 2).

Table 2. Energy institutional analysis in the three urban agglomerations

\begin{tabular}{|c|c|c|}
\hline Region & $\begin{array}{c}\text { Common } \\
\text { Characteristics }\end{array}$ & $\begin{array}{c}\text { distinctive } \\
\text { characteristics }\end{array}$ \\
\hline BTH & \multirow{3}{*}{$\begin{array}{l}\text { (1)Pay attention to } \\
\text { energy related } \\
\text { marketization reform } \\
\text { of electric power } \\
\text { (2) Attach importance } \\
\text { to promoting the } \\
\text { development of clean } \\
\text { energy } \\
\text { (3)Promoting the } \\
\text { separation of energy } \\
\text { regulation and policy } \\
\text { making }\end{array}$} & $\begin{array}{l}\text { The BTH focuses on } \\
\text { energy marketization } \\
\text { for the development of } \\
\text { renewable energy }\end{array}$ \\
\hline YRD & & $\begin{array}{l}\text { The YRD attaches great } \\
\text { importance to the } \\
\text { reform of power system } \\
\text { to make full use of clean } \\
\text { energy }\end{array}$ \\
\hline PRD & & $\begin{array}{l}\text { The Pearl River Delta } \\
\text { puts the energy } \\
\text { legislation system in the } \\
\text { first place and improves } \\
\text { the energy utilization } \\
\text { efficiency } \\
\text { fundamentally }\end{array}$ \\
\hline
\end{tabular}

(1) energy legislation and regulation system. The three urban agglomerations' government have form different energy system under the basis of renewable energy law. For example, the BTH attach more importance to the role of renewable energy accommodation. The YRD put an 
emphasis on energy price mechanism. On the contrary, the PRD tend to Green quota system.

(2) energy marketization. Promoting the energy market liberalization is consensus of the three urban agglomerations, which is conducive to play the role of market to allocate energy ${ }^{[21]}$. However, the degrees of government intervention and the energy marketization in each urban agglomeration are different. For example, the governments of the BTH and the YRD establish a competition mechanism for the renewable energy market. In contrast, the government of the PRD has not an efficiency renewable energy market to promote the energy transition.

(3) energy regulatory. it has become a consensus among the three urban agglomerations to separate the energy regulatory agencies from the policy-making agencies. For example, the regulatory authority in the PRD is the regulatory department, and the policy making is the legislative department.

\subsection{Economic aspect}

With the economic development entering a "new normal" (New Normal is defined by Chairman Xi Jinping, which means Chinese economy is to return to normal after a period of abnormal state), China's energy development has shown a "low growth rate, low increment, low carbonation" trend ${ }^{[22]}$. The normal economic growth rate will help alleviate the tension in energy resources, environment and fundamentally alleviate overcapacity.

With reference to energy economic, energy investment and accommodation of renewable energy are crucial for it. When comes to energy investment, according to the China Energy Investment 2019 released by the national energy administration, it is well known that investment fields is mainly concentrated on industry sector, power sector, and renewable energy. As for renewable energy accommodation, the installed capacity of renewable energy is necessary to be considered. (1) The share of renewable energy utilization in the three regions has gradually increased. The installed capacity of renewable energy generation is becoming increasingly competitive. Except for Zhejiang Province, the share of renewable energy power accommodation in various provinces (Polaris Electric Power,2016), the percentage of other provinces is increasing. It is suggested that to highlight renewable energy development is necessary. (2) From 2012 to 2018, the installed capacity of renewable energy (including wind, solar, hydro, and nuclear) has continued to increase (Table 3). For instance, the installed capacity in the BTH increased from $140 \mathrm{MW}$ to $279 \mathrm{MW}$ between 2012 and 2018. Additionally, the installed capacity in the PRD in 2018 increased by 1.6 times compared with 2012.

Table 3. Renewable energy installed capacity in three agglomerations

\begin{tabular}{|c|c|c|c|}
\hline \multirow{2}{*}{ Year } & \multicolumn{3}{|c|}{ Installed capacity (GW) } \\
\cline { 2 - 4 } & BTH & YRD & PRD \\
\hline $\mathbf{2 0 1 2}$ & 14.00 & 771.80 & 677.80 \\
\hline $\mathbf{2 0 1 3}$ & 174.10 & 695.80 & 729.40 \\
\hline
\end{tabular}

\begin{tabular}{|l|l|l|l|}
\hline $\mathbf{2 0 1 4}$ & 192.10 & 731.90 & 839.40 \\
\hline $\mathbf{2 0 1 5}$ & 204.80 & 892.90 & 964.90 \\
\hline $\mathbf{2 0 1 6}$ & 246.20 & 957.30 & 1108.40 \\
\hline $\mathbf{2 0 1 7}$ & 285.00 & 989.91 & 1181.40 \\
\hline $\mathbf{2 0 1 8}$ & 287.90 & 1163.01 & 1095.40 \\
\hline
\end{tabular}

\subsection{Technical aspect}

Energy technology innovation can effectively promote the development of clean energy and efficient use of fossil energy ${ }^{[23]}$. Due to the difference in variety energy resource characteristic, energy transition pathway of each agglomeration. According to "Energy Technology Revolution Innovation Action Plan (2016-2030)" was proposed by National Development and Reform Commission and national energy administration. We divide energy technology into two kinds of type, one is renewable energy technology, the other is energy saving and emission reduction technology (Table 4). (1) Technologies in the three urban agglomerations have something in common: for example, the purpose of technology innovation is to promote renewable energy or improve energy utilize efficiency. Furthermore, energyintensive enterprises, such as industry, transport and building fields, pay more emphasis on energy-saving technology. On the contrary, energy-supply enterprises, such as production field, attach importance on Renewable energy technology. (2) The development direction of energy technology in various agglomerations is different. For example, the BTH focuses on industrial and building energy-saving technologies, since the BTH has many high-energy-consuming industries. In contrast, the YRD emphasizes the renewable technologies development. (3) Energy technologies can actively improve energy efficiency. Renewable energy technologies are being developed in order to reduce the costs of the generated electricity and increasing technological performance. Moreover, wind energy has been recognized as a secure and reliable low-carbon technology.

\subsection{Behaviour aspect}

Governments and enterprises are the main body in the energy transition ${ }^{[24]}$. The government behaviour has an impact on the enterprise behaviour, and the enterprise behaviour can provide decision-making basis for government policy making. The government behaviour and the enterprise behaviour jointly promote energy transition.

\subsubsection{Government behaviour}

To ensure that the process of energy transition enters into a healthy and orderly development track, the governments in the three urban agglomerations have taken actions to promote energy transition. (1) Due to the difference in energy endowment, especially in terms of energy consumption and cleaner production, energy conservation and emission reduction. The governments in the three urban agglomeration have their own unique behaviour to promote energy transition (table 5). In response to 
comprehensively promote the energy transition, governments have formulated various energy relevant development plan, notice, measure and regulation. (2) Governments Behaviour in this paper can be roughly divided into setting targets, energy regulatory, and making policies. The governments in the three agglomerations have different priorities, the BTH government centered on subsidy policies. The YRD government tends to action plans, whereas the PRD government is mainly development planning. (3) Due to the monopoly of power grid enterprises and the opacity of information, governments in the three agglomerations regulate the energy market and the pipeline networks to ensure fair transactions. In addition, optimizing the energy supply structure of the power industry is the focus of energy transition in the three agglomerations. And the power as a clean energy is a key industry of energy transition, and provides clean and low-carbon power move to the center of the three agglomerations.

\subsubsection{Corporate behaviour}

Enterprises are the main body of energy-consuming, and the energy enterprises behaviour in the three major urban agglomerations have similar things. (1) Enterprises in the three agglomerations pay attention to the technology development and application. The enterprises are expected to reduce costs and carbon emission to achieve the expected goals by technical tools. For example, China National Nuclear Corporation have established energy management systems and improved long-term energysaving mechanisms [25]. (2) Enterprises in the three agglomerations obey the government policies. And government subsidy policies can help increase the R\&D input intensity of new energy enterprises, which is conducive to their growth . Taking BTH as an example, the BTH government chooses clean energy as an alternative energy, such as natural gas, hence the enterprises in the BTH take technology innovation to promote clean energy development (table 6).

In terms of different development goal of enterprises, there are differences in the enterprises behaviour among the three urban agglomerations: (1) As the enterprise behaviour is influenced by both the state aspect and the local aspect, the enterprise behaviour development direction is different from urban to urban. For instance, the BTH government regards renewable energy as the main energy source in the future, so that BTH enterprises pay more attention to renewable energy development. On the contrary, some YRD enterprises have developed hydrogen energy under the guidance of the government, but they have also developed conventional energy to meet the market demand. (2) Enterprises in the three regions take different approaches to the clean and efficient use of coal. For example, the YRD uses key technologies for ultra-low emissions of coal-fired units, while BTH utilizes coal gasification and recycling technology.

\section{Conclusions}

Currently, energy transition in the three urban agglomerations has been made certain progress. Nevertheless, there are many obstacles still stand in front of China's energy transition. In order to overcome the obstacles, this paper uses the Institution-EconomyTechnology-Behaviour (IETB) conceptual model to analyse the energy transition in the three urban agglomerations. In addition, the energy situation, the energy polices, the energy technologies and the behaviour of participants are discussed. In summary, three remarks are made to conclude this research.

Firstly, the energy transition in the three urban agglomerations has three aspects impact on China's energy transition. (i) From the perspective of energy development, the three urban agglomerations promoting renewable energy development and optimizing energy structure, which make a basis for China's energy transition (ii) In terms of energy institution and participants behaviours, the governments and enterprises have been made common efforts in the three urban agglomerations, they are guiding China's energy transition to using the low-carbon and clean energy. (iii) On the economy development and the energy technology, the massive energy investment and technological innovation in the three urban agglomerations accelerate the process of China's energy transition.

Secondly, the energy transition in the three urban agglomerations has three difficulties. (i) from the perspective of the institution and behaviour, the energy management system of each agglomeration is based on its specific situation and needs to make choices. The "Government supervisor separation" have not completely achieve their own advantages. (ii) economic investment has a significant role in the promotion of new energy development. Therefore, the energy investment should focus on the direction that has an impact on promoting energy transition. (iii) Although the new energy and renewable energy technologies are gradually industrialized, the equipment technology of the energy industry has not widely developed, and the innovation capability of energy technologies has not improved.

Finally, in order to achieve better energy transition in the three urban agglomerations, three measures should be considered: (i) The renewable portfolio standard for renewable energy development should be accomplished. The mechanism and policy on the electricity price of renewable energy should be promoted to facilitate renewable energy accommodation. (ii) Additionally, the technology is one of the driven forces of energy transition. We should strengthen the application of energy-saving and renewable energy technologies. And the equipment technology scale should be expanding in high-consuming industry. (iii) The governments are recommended to ensure the proper implementation of policies to abate the environmental consequences of conventional energy sources. And certain government intervention is needed on the pathway of energy transition. 


\section{Appendix}

Table 4. Technologies related to energy transition

\begin{tabular}{|c|c|c|c|c|c|c|}
\hline \multirow[t]{2}{*}{ Region } & \multicolumn{3}{|c|}{ Renewable energy technology } & \multicolumn{3}{|c|}{$\begin{array}{l}\text { Energy saving and emission reduction } \\
\text { technology }\end{array}$} \\
\hline & Categories & purpose & characteristic & Categories & purpose & application \\
\hline \multirow{3}{*}{$\begin{array}{l}\mathrm{BT} \\
\mathrm{H}\end{array}$} & solar photovoltaic & adjust energy supply & Power sector & CCUS & pollution & Industry sector \\
\hline & wind technology & & $\begin{array}{l}\text { Industry } \\
\text { sector }\end{array}$ & IGCC & control & \\
\hline & $\begin{array}{l}\text { geothermal } \\
\text { energy }\end{array}$ & & $\begin{array}{l}\text { Industry } \\
\text { sector }\end{array}$ & SEE & $\begin{array}{l}\text { energy } \\
\text { saving }\end{array}$ & Power sector \\
\hline \multirow[t]{3}{*}{$\begin{array}{l}\text { YR } \\
\mathrm{D}\end{array}$} & solar heating & promote clean energy & $\begin{array}{l}\text { Building } \\
\text { sector }\end{array}$ & IGCC & $\begin{array}{l}\text { pollution } \\
\text { control }\end{array}$ & Industry sector \\
\hline & Nuclear power & Satisfy energy supply & Power sector & CCET & $\begin{array}{l}\text { Improve } \\
\text { efficiency }\end{array}$ & Power sector \\
\hline & Offshore Wind & Satisfy energy supply & Power sector & HTGCR & pollution & \\
\hline \multirow[t]{3}{*}{ PRD } & solar photovoltaic & $\begin{array}{l}\text { Develop renewable } \\
\text { energy }\end{array}$ & $\begin{array}{l}\text { Building } \\
\text { sector }\end{array}$ & HEFMW & cont & Transportation \\
\hline & Offshore Wind & Satisfy energy supply & Power sector & CCUS & & Industry sector \\
\hline & $\begin{array}{l}\text { Hydrogen } \\
\text { technology }\end{array}$ & $\begin{array}{l}\text { Strength energy- } \\
\text { saving }\end{array}$ & $\begin{array}{l}\text { Industry } \\
\text { sector }\end{array}$ & DOGET & $\begin{array}{l}\text { energy } \\
\text { saving }\end{array}$ & Industry sector \\
\hline
\end{tabular}

Note: CCUS: Carbon capture, utilization and storage

IGCC: Integrated gasification combined cycle

SEE: Storage of electrical energy

CCET: clean and efficient technology

HTGCR: High-temperature gas-cooled reactor

HEFMW: Harnessing energy from manmade waste

DOGET: deep oil and gas exploration technologies

Table 5. Government behaviour

\begin{tabular}{|c|c|c|}
\hline region & Behaviour & Government specific actions \\
\hline ВTH & & $\begin{array}{l}\text { (1)The Local Energy Administration is responsible for formulating local energy } \\
\text { development goals and strategies. } \\
\text { (2) The Energy Agency is responsible for regulating the power network and } \\
\text { ensuring a balanced distribution of benefits. } \\
\text { (3) The BTH government formulates national energy development strategies and } \\
\text { energy transition goals. }\end{array}$ \\
\hline YRD & $\begin{array}{l}\text { (1) Setting targets } \\
\text { (2)Energy regulatory } \\
\text { (3) Making policies }\end{array}$ & $\begin{array}{l}\text { (1)The YRD government formulates energy transition strategies to promote } \\
\text { renewable energy development. } \\
\text { (2) The Energy Administration's Regulation Department regulates the electricity } \\
\text { market and energy pipeline networks. } \\
\text { (3)The YRD government sets greenhouse gas reduction targets and formulates } \\
\text { strategies for the development of clean energy. }\end{array}$ \\
\hline PRD & & $\begin{array}{l}\text { (1)The PRD government formulates its own energy development strategies and } \\
\text { energy transition goals. } \\
\text { (2)The Office of Gas and Electricity Markets regulates the power grid, } \\
\text { electricity market and natural gas market. } \\
\text { (3)The Electricity and Gas Market Surveillance Commission regulates the } \\
\text { electricity, natural gas and thermal energy trading markets. }\end{array}$ \\
\hline
\end{tabular}

Table 6. Corporate behavior

\begin{tabular}{|c|c|c|c|c|}
\hline \multirow{2}{*}{ region } & \multicolumn{2}{|c|}{ Corporate behaviour } & \multirow{2}{*}{$\begin{array}{c}\text { Behaviour of a typical } \\
\text { enterprise }\end{array}$} \\
\cline { 2 - 3 } & Energy-intensive enterprises & $\begin{array}{c}\text { conventional energy } \\
\text { enterprises }\end{array}$ & $\begin{array}{c}\text { renewable } \\
\text { energy } \\
\text { enterprises }\end{array}$ & \\
\hline
\end{tabular}




\begin{tabular}{|c|l|l|l|l|}
\hline BTH & $\begin{array}{l}\text { Strengthen technological } \\
\text { innovation, increase energy } \\
\text { conservation and } \\
\text { environmental protection }\end{array}$ & $\begin{array}{l}\text { Actively promote } \\
\text { resource conservation } \\
\text { and recycling }\end{array}$ & $\begin{array}{l}\text { Adhere to the } \\
\text { development } \\
\text { of clean } \\
\text { energy }\end{array}$ & $\begin{array}{l}\text { The CNPC vigorously } \\
\text { developed the clean } \\
\text { energy and clean energy } \\
\text { technologies }\end{array}$ \\
\hline YRD & $\begin{array}{l}\text { Focus on efficient and clean } \\
\text { energy equipment }\end{array}$ & $\begin{array}{l}\text { Implement the whole } \\
\text { process pollution } \\
\text { control }\end{array}$ & $\begin{array}{l}\text { Combined use } \\
\text { of multiple } \\
\text { energy }\end{array}$ & $\begin{array}{l}\text { The Baosteel formulated } \\
\text { carbon emission targets } \\
\text { and took proactive actions } \\
\text { to reduce its own carbon } \\
\text { emissions }\end{array}$ \\
\hline PRD & $\begin{array}{l}\text { Promoting green energy } \\
\text { technology to make } \\
\text { transportation clean }\end{array}$ & $\begin{array}{l}\text { Strength the } \\
\text { production and supply } \\
\text { of clean energy }\end{array}$ & $\begin{array}{l}\text { Enhanced new } \\
\text { energy power }\end{array}$ & $\begin{array}{l}\text { The CNNC developed } \\
\text { low-carbon technologies to } \\
\text { reduce the negative impact } \\
\text { of energy production }\end{array}$ \\
\hline
\end{tabular}

Note: $\mathrm{CNPC}=$ China National Petroleum Corporation

Baosteel $=$ China BAOWU Steel group

$\mathrm{CNNC}=$ China National Nuclear Corporation

\section{Acknowledgment}

This work is supported by the Technological Project of State Grid Corporation of China (SGCC) (Grant No. 1400-202057226A-0-0-00) and the Shanghai Philosophy and Social Science Planning Project (Grant No. 2018EJL001).

\section{References}

1. Shi Yunlong. (2014) Analysis and Countermeasures on Economic Growth and Energy Consumption in the Pearl River Delta, Yangtze River Delta, and Bohai Rim Economic Circle [J]. Economic Research Guide, 12:8-9+12.

2. He Jiankun. (2015) Strategic choice of China's energy revolution and low-carbon development [J]. Journal of Wuhan University (Philosophy and Social Sciences), 1: 5-12.

3. Zhang Qi. (2018) Challenges and prospects of China's energy production and consumption revolution [J]. National Governance, 33: 3-12.

4. Li Junjiang, Wang Ning. (2019) China's Energy Transition and Path Selection [J]. Administration Reform, 5: 65-73.

5. Ma Jiantang. (2019) Meeting the global energy transition and realizing high-quality development of China's energy [N]. China Economic Times

6. Luo Xiaofei. (2005) From "oil shortage" to sustainable development: strategies for energy structure adjustment in Guangdong Province [J]. Coastal Enterprises and Science and Technology, 12: 127-129.

7. Lin Boqiang. (2019) Increasing innovation to promote energy structure adjustment $[\mathrm{J}]$. Coal Information Weekly, 18:

8. Tang Yutu, Zhang Longyan. (2016) Analysis of photovoltaic power generation development strategy of a company based on PEST and SWOT analysis methods [J]., 12 :15-16.

9. Liu Pingkuo, Peng Huan,Luo Sai. (2019) Research on the structural characteristics of the driving forces of China's energy transition. China Population, Resources and Environment, 12:45-56.

10. Bolwig S, Bazbauers G, Klitkou A, Lund P D,Blumberga A, Gravelsins A, Blumberga D. (2019) Review of modelling energy transitions pathways with application to energy system flexibility[J]. Renewable and Sustainable Energy Reviews, 101:440-452.

11. Zhu Tong. (2015) Barriers to energy transition [N]. China Coal News.

12. Zhan Yingxia. (2018) Forecast of Energy Supply and Demand in Hebei Province and Analysis of Development Countermeasures [D]. Hebei University of Economics and Trade.

13. Zhang Xiaoxuan, Huang Guohe, Xi Beidou, Xu Hong, Niu Yantao. (2008) The main problems and countermeasures of Beijing's energy system [J]. Energy Conservation and Environmental Protection, 05: 15-17.

14. Wang Hao. (2009) Analysis of Energy Development and Utilization in Tianjin [J]. City, 05: 68-71.

15. Mo Shenxing. (2010) Establishing an Optimized Energy Structure Mechanism and Building a LowCarbon Yangtze River Delta [J]. Shanghai Electric Power, 01: 5-12.

16. Zhu Yuanxiu, Xu Changle. (2014) Evaluation of the process of transition and development in the Yangtze River Delta [J]. East China Economic Management, 09: 59-65.

17. Wang Ronggui. (2011) Research on Energy Supply and Demand Forecast and Development Countermeasures of Guangdong Province [D]. Jinan University.

18. Zhang S, Andrews-Speed. (2020) State versus market in China's low-carbon energy transition: An institutional perspective. Energy Res. Soc.

19. Tian Qiyun. (2019) The Institutional Path of Renewable Energy Development under the Background of Green Energy Revolution [J]. Zhongzhou Academic Journal, 07: 89-94.

20. Xi Binxian, Liu Xiaohong. (2019) Interregional Differences in Air Pollution, Influencing Factors and Governance Policy Choices: Based on a Comparative Analysis of the Yangtze River Delta, Beijing, Tianjin, 
Hebei, and Pearl River Delta [J]. Bulletin of Science and Technology, 08: $197-202$.

21. Li Zhixue, Qin Zirui, Wang Huanhuan.(2019) Research on China's wind power cost level and its influencing factors [J]. Price Theory and Practice, 10: 24-29.

22. Yu Xi, Zhao Hailan. (2018) Path of energy conservation and emission reduction: Based on the behavior characteristics of energy consumers [J]. Modern management science, 03: 82-84.
23. Xu Liping. (2018) Many energy companies are shortlisted for the "Double Hundred Action" [N]. China Energy News.

24. Yang Jie. (2017) Research on the Impact of Government Carbon Regulation on Carbon Emission Reduction Behaviour of Cold Chain Logistics Enterprises [D]. Nanchang University of Aeronautics.

25. Sun Yingfen. (2019) Development of EU Enterprises from the Perspective of Renewable Energy and Its Enlightenment to China [J]. Knowledge Economy, 34: 9-10 